\title{
Linguistic Paradoxes and Cultural Domination
}

\author{
Amy B.M. Tsui \\ The University of Hong Kong
}

Spring (this volume) provides an interesting account of the global flow of education ideas and how it has always been largely motivated by a fear of the "other". In the past, fear of western imperialism had caused Asian countries to westernize their school systems and open their doors to American progressive education. Similarly, fear of the rise of Asian countries had also caused western countries to take Asian models of education seriously. The globalized economy, according to him, has speeded up the flow of educational ideas and the spread of industrial-consumerism. This has led to emergence of the educational security state as the dominant educational model. In his article, Spring examines in particular the rapid spread of English in Asia and the fear of the "other" intensified by globalization. He observes that much of the teaching of English, however, is mediated by local cultural traditions. For example, English is taught through local stories and legends, and not just through American and British literature. Conversely, western cultures and consumerism are mediated through local languages. He argues that though English has become the language of the global economy because of the history of English imperialism, it is no longer a tool for imperialist domination but one for participation in the global economy. The spread of English is self-imposed in nonEnglish mother tongue countries rather imposed by external forces. Moreover, what it propagates is consumerism rather than western cultures and values. Hence, globalization 
has created a hybridity of language and culture: a language of global brands and a culture of global consumerism.

In this paper, I wish to focus on the spread of English and address two aspects in relation to it: First, the linguistic paradox created by the spread of English and second, the cultural domination that accompanies the spread of English.

\section{The spread of English and linguistic paradox}

As Spring rightly points out, the intensified spread of English is a result of choice rather than coercion. In Tsui and Tollefson (2007), we have reviewed the language policy responses to globalization in twelve Asian countries and observed that compared to English mother-tongue countries, Asian countries are even more culpable of spreading English, hence legitimating the hegemony of English. The lived experiences of these countries resonate with Spring's observation that even in countries that are keen to preserve of the integrity of their own cultures, and those which are highly apprehensive of cultural contamination from the West and suspicious of the political motivation of Western superpowers, the learning of English has been vigorously promoted by placing it high on their national language policy agenda and their national economic strategies for fear that they might lose out in the global competition. Enormous amounts of resources have been poured into the learning of English, even in countries that are still suffering from a high illiteracy rate and extreme poverty (Tsui \& Tollefson, 2004).

Spring points out that in some countries English has been adopted for utilitarian purposes with no detriment to local cultural values. This is reminiscent of Conrad's argument that many people in non-English mother tongue countries "are fully fluent in 
English, even speak it as their principle language, with no loss of their cultural identity” (1996, p. 21). However, language is not merely a technical tool. It is a cultural artifact created within specific sociocultural and historical contexts, and thus embodies the cultural values, histories, traditions and beliefs embedded in those contexts. Therefore, the promotion of English in non-English mother tongue countries, often over and above their own national languages, raises the question of its impact on their national cultural identities. Our examination of the language policy responses of Asian governments, as evidenced in discourses in official documents, curriculum materials and the media, has revealed a linguistic paradox in which national cultural identities are being constructed through the very discourse which legitimates the hegemony of English. For example, in Japan, English is promoted by “deconstructing” it as a mere technical tool while Japanese cultural values are preserved through the emphasis on "Japaneseness", and cultural as well as political independence are protected by looking for solutions to challenges posed by globalization from “the frontier within” (literally translated as “Japan’s frontier lies within Japan”) rather than from the West (Hashimoto, 2007, pp. 27, 30). In South Korea, English language education has become the focus of educational reform which is one of the priority areas in its globalization policy. At the same time, the assimilation of Western culture brought about by the "English study fervor" (young uh yul poong) and its impact on Korean culture and national identity have become a cause for concern for its people and its government (Yim, 2007). Yim’s analysis of curriculum materials approved by the South Korean government shows that English is constructed as a tool to put the country on the world map, to promote Korean culture to the international community, to inculcate national pride and to strengthen national identity. Citing an old Korean proverb, "In order 
to win, know your enemy better”, Yim suggests that the promotion of English by the government has been premised on the assumption that "Korea can only overtake its competitors by getting intimately familiar with them", and understanding English is the first step to gain familiarity with the worlds' most powerful and competitive nations (2003, p. 42). This is echoed by the Malaysian government which, as a consequence of the adverse effects of globalization on its economy, sees the rest of the world as harsh and hostile. English is reconstructed as a tool that will help Malaysia to gain economic power and consequently reinforce the spirit of nationalism, and as a weapon that will help Malaysia to contest against the rest of the world (Gill, 2002; Tsui \& Tollefson, 2007). Similar to South Korea, the English curriculum is appropriated as a tool for promoting Malaysia as a harmonious and cohesive multi-cultural and multi-ethnic country to the international as well as the intra-national communities (David \& Govindamsamy, 2007). In China, English is no longer the language of imperialists and learning English has been exalted as a national mission (Jin \& Cortazzi, 2004). One of the goals of in the New English Curriculum for Schools released in 2005 is to enhance patriotic education. However, similar to Malaysia and South Korea, global competitions have been constructed as "economic wars" and knowledge of English is crucial to enable China to win these wars through global participation (Moore, 2000). Spring points out that combating imperialists was the ultimate goal for learning their language(s) in the sixties for Japan, China and Vietnam. Today, the picture is more complex but what has remained the same, though in more subtle forms, is that foreign languages are learnt not just for the purpose of international understanding and collaboration, but also for national security and global competition (as in the case of US after 9/11; see also Kramsch, 2005). It is 
unmistakable that in the globalization processes, boundaries are being set up as they are being torn down, and we become alienated and mistrustful as we become connected. Globalization, as Spring contends, has intensified the fear of the "other”. The spread of English is not culturally neutral, nor is it politically neutral; at least it is not perceived as such by Asian governments.

\section{Linguistic and cultural domination}

\section{Models and varieties of English}

While the spread of English may not be considered a form of cultural imperialism, we must not overlook the fact that linguistic and cultural domination of a more subtle variety is pervasive. As Clayton (2002) (cited by Spring as well) points out, the linguistic preferences of multinationals and international organizations, still largely dominated by developed countries, have shaped the language choices of developing countries. In countries like Cambodia, Nepal and Bangladesh, their preferences are the sole factor that determines their language policies (Clayton, 2007; Hoosain \& Tollefson, 2007; Sonntag, 2007).

Spring notes the recognition of the legitimacy of varieties of English other than British and American, reified as "Standard" English, and the coining of the word “Englishes”. However, as pointed out in Tsui and Tollefson (2007), in many Asian countries, the variety of English that is put forward as the model is "Standard" English. In Singapore, a Speak Good English Movement, first initiated in the late 70s, was relaunched in 2000. Although British RP (Received Pronunciation) had been replaced by a local variety of "Standard English" which is internationally intelligible (Chew, 2007), the 
question of who sets the "Standard” is still pertinent. In Hong Kong, English language testing instruments designed in the US and in UK, including the IELTS, designed by the British, have been used for recruitment purposes by government and the business sector. All prospective and practising school teachers of English are required to pass English benchmark assessments in order to join or stay in the profession. Although the test designers have carefully specified that the model of English required is that of an educated English speaker, it is the "native-speaker" variety that is being regarded as the authority by teachers, educational authorities and employers (Tsui \& Bunton, 2000; Bunton \& Tsui, 2002). In China, students’ written and spoken English in the College English Tests are being extensively researched and native-speaker of English (NSE) corpora, such as the British National Corpus, have been used as the norm for diagnostic purposes (Tsui, 2004).

In a number of Asian countries, NSEs--British and American, and in recent years Australian as well--have been recruited to teach in schools and universities. Singapore had such a recruitment scheme for schools in place thirty years ago, in the late 70s. Japan followed suit ten years later and introduced the JET program in 1987. Hong Kong introduced the NET scheme also in the 80s, followed by South Korea in the 90s. Such schemes were set up with an implicit criticism of the English competence of local English teachers. For example, in South Korea, NSE teachers are believed to be "more effective" than local teachers (Yim, 2003).

In Japan, American English is taken as the model. According to Nonna, Tajima and Minamoto (2004), learners do not see non-native varieties of English positively. They are ashamed if they do not speak the way NSEs do and they are reluctant to use 
English until they have developed “complete proficiency in the language” (p. 154). Moreover, "behavioral acculturation is also a presupposed necessity” (ibid.). Similarly, in South Korea, white middle-class British and American English is used as the model in the English school curriculum (Yim, 2007).

\section{Communication skills and cultural values}

Globalization has created a great demand for oral communication in English because of the mobility of the work force and students beyond geographical and national boundaries. To meet this demand, the English curricula in Asian countries have shifted the focus from reading, grammar and translation skills to the four language skills, particularly listening and speaking. This curriculum shift has important implications for Asian countries whose cultural traditions are rooted in Confucian Heritage Culture (CHC) (Biggs, 1996), including China, Japan, South Korea, Vietnam and Singapore.

CHC countries share some common cultural characteristics, being influenced by Confucian thinking in one way or other. I hasten to add that this does not represent an essentialist view nor am I trying to present cultural stereotypes. Admittedly, there are variations between individuals and within groups, and such variations are often situated. However, we cannot deny that cultural traditions do play an important role in shaping one's view of the world. The following are some of the deeply rooted cultural beliefs in these countries.

Reticence is highly valued in CHC. In the Chinese culture, it is considered an important attribute, alongside mental strength and perseverance, of a good person (ren). In a narrative inquiry of EFL teacher and learner identities that I conducted recently, an 
EFL teacher in China narrated that when he was an EFL learner, he could not relate to the communicative language teaching approach adopted from the West which required students to provide spontaneous responses to the teacher's questions. He felt that this went against the Chinese culture which attached a great deal of importance to deep thinking before expressing one’s views. He resented being asked to assume a different persona and did not feel that he benefited from that learning style (Tsui, in press). Similarly, in the Japanese culture, reticence is considered an important quality. Nonna et al. (2004) point out that the emphasis on oral participation goes against the Japanese culture of sasshi (tacit understanding) which can be seen from proverbs such as "make one point and get 10 points across" (ichi wo ieba juu ga wakaru) and "You have to say nothing to communicate what you are thinking” (iwanakutemo wakaru). Speech is considered obstructive to harmonious human relationships and Japanese people often get things done without using words.

Another characteristic of CHC is indirectness. In both Japanese and Chinese cultures, disagreements are seldom voiced in public and put forward directly. Interlocutors look for clues such as facial expressions and tones, and read between the lines to get the real intention of the speaker and the writer. According to Nonna et al. (2004), such culture has a great deal to do with the closely knit communities in Japan where members share a large common ground. "The function of language as a means of social communication," they point out, "is not to state facts and opinions, but to maintain the feeling of homogeneity.” (Nonna et al., 2004, p. 146). This cultural tradition, they point out, is a "major problem" in learning English (ibid.). They make an appeal not to be forced to abandon their native culture in order to acquire English proficiency. 
Cultural differences have also been highlighted by Pham (2000) and Phan and Faulkner (2000) in their analyses of why tertiary English language training programs did not work in Vietnam. According to them, Vietnamese educational philosophies have been influenced by Confucian educational values which view learning as transmission of knowledge and an analysis of ideas. Memorizing is an important learning strategy. In learning English, Vietnamese students, similar to Chinese students, pay meticulous attention to linguistic details and the explication of text (see also Tsui, in press). Like Japanese students, Vietnamese learners are reluctant to speak unless they feel that they have an adequate command of the language. According to Pham (2000), Vietnamese students believe that they cannot say anything before acquiring enough grammar rules and vocabulary.

Learning another language involves changing the way one relates to other people; it challenges one's perception of "self” and the essential qualities of being a good person. The psychologically unsettling effect of enculturation on learners should not be underestimated.

\section{Language pedagogy and cultures of learning}

In the discourse on pedagogy and learning styles, cultural domination is realized in discussions of pedagogical practices by both Asian and non-Asian researchers and practitioners. Asian students have been described as passive, uncritical, engaging in rote learning and low-level cognitive strategies (see Biggs, 1996; Nozaki, Openshaw \& Luke, 2005). Asian teachers have been described as traditional, teacher-centred, focused on transmission of knowledge and drill-oriented. These views are Anglo-centric and are 
formed by imposing conceptual frameworks which have been developed largely on the basis of analyzing data without situating them in the sociocultural contexts in which they were generated.

These views, which have dominated the EFL discourse for a long time, have had a detrimental effect on the self-esteem of non-native speaker of English (NNSE) teachers and learners. For example, the EFL learner in my study was stigmatized a “dumb-anddeaf English learner” because he was averse to the communication style and was reticent in class (Tsui, in press). In Brogan and Nguyen’s study (2000), imported materials were given credibility over materials produced by local teachers even when they were inappropriate for the target group. Teachers and students alike did not believe that NNSE teachers could produce useful and meaningful teaching materials. Consequently, the same set of materials was used for different types of learners and for different purposes, including, government officials for international interaction, engineers for completing technical tasks, and students for studying abroad. Yet, students were accused of being "lazy or even stupid" when they did not understand imported materials.

In recent years, the consistent outstanding performance of Asian students in the International Education Assessment studies and the equally consistent discourse about the low quality of learning of Asian students in the research literature have led to a number research studies trying to solve this paradox. The ground-breaking comparison of Asian and Western learners of mathematics conducted by Stevenson and Stigler (1992) and Stigler and Hierbert (1999) have shown that Japanese and Chinese learners learnt mathematics more effectively compared to their U.S. and German counterparts precisely because the classroom was not "student-centred" but focused on the object of learning 
which was the mathematical concept being taught. Similarly, a number of subsequent studies of classroom learning in China have shown that the quality of learning in these “teacher-centred classrooms” were high because the object of learning was clearly defined, thoroughly interrogated amongst learners, and scaffolded by the teachers’ meticulous choreographing of the lessons (Ma, 1999; Marton \& Tsui, 2004; Paine, 1990). There is now an emerging body of research which aims to rediscover the wealth of knowledge about teaching and learning embedded in diverse cultural practices.

The spread of English, intensified by globalization, is therefore not as culturally neutral as it has been portrayed or as we may wish it to be. The subtle forms of linguistic and cultural domination and the resistance to domination that it has brought about, and will continue to do so, should not be overlooked because instead of enhancing intercultural understanding and empowering the powerless, they could exacerbate social and economic divides, disempower the powerless, and engender mistrust and hatred intra-nationally as well as internationally.

\section{References}

Biggs, J. (1996). Western misconceptions of the Confucian-heritage learning culture. In D. Watkins \& J. Biggs (Eds.), The Chinese learner (pp. 45-68). Hong Kong: Comparative Education Research Centre and Australian Council for Educational Research.

Brogan, M., \& Nguyen, T. H. (2000). The 3 R's of teacher training in Vietnam: Revising, reviving and researching. Paper presented at the Teaching at the Mekong Institute: 
applying the AIM approach. Proceedings of the Fourth International Conference on Language and Development, Hanoi, Vietnam.

Bunton, D., \& Tsui, A. B. M. (2002). Setting language benchmarks: Whose benchmark? Journal of Asian Pacific Communication, 12(1), 63-76.

Chew, P. G. L. (2007). Remaking Singapore: Language, culture, and identity in a globalized world. In A. B. M. Tsui \& J. Tollefson (Eds.), Language policy, culture, and identity in Asian contexts (pp. 73-93). Mahwah, N.J.: Lawrence Erlbaum Associates.

Clayton, T. (2002). Language choice in a nation under transition: The struggle between English and French in Cambodia. Language Policy, 1(1), 3-25.

Clayton, T. (2007). Transition, culture, and language in Cambodia. In A. B. M. Tsui \& J. W. Tollefson (Eds.), Language policy, culture, and identity in Asian contexts (pp. 95117). Mahwah, N.J.: Lawrence Erlbaum Associates.

Conrad, A. W. (1996). The international role of English: The state of the discussion. In J. Fishman, A. Rubal-Lopez \& A. W. Conrad (Eds.), Post-imperial English: Status change in former British and American colonies, 1940-1990. (pp. 13-36). Berlin: Mouton de Gruyter.

David, M. K., \& Govindasamy, S. (2007). The construction of national identity and globalization in multilingual Malaysia. In A. B. M. Tsui \& J. W. Tollefson (Eds.), Language policy, culture, and identity in Asian contexts (pp. 55-72). Mahwah, N.J.: Lawrence Erlbaum Associates. 
Gill, S.-K. (2002). Language policy and English language standards in Malaysia:

Nationalism versus pragmatism. Journal of Asian Pacific Communication, 12(1), 95116.

Hashimoto. (2007). Japan's language policy and the "lost decade". In A. B. M. Tsui \& J. W. Tollefson (Eds.), Language policy, culture, and identity in Asian contexts (pp. 2536). Mahwah, N.J.: Lawrence Erlbaum Associates.

Hossain, T., \& Tollefson, J. W. (2007). Language policy in education in Bangladesh. In A. B. M. Tsui \& J. W. Tollefson (Eds.), Language policy, culture, and identity in Asian contexts (pp. 241-257). Mahwah, N.J.: Lawrence Erlbaum Associates.

Jin, L., \& Cortazzi, M. (2004). English language teaching in China: A bridge to the future. In K. W. Ho \& R. Y. L. Wong (Eds.), English language teaching in East Asia today: Changing policies and practices (pp. 119-134). Singapore: Eastern University Press.

Kramsch, C. (2005). Post 9/11: Foreign languages between knowledge and power. Applied Linguistics, 26(4), 545-567.

Ma, L. P. (1999). Knowing and teaching elementary Mathematics: Teachers' understanding of fundamental mathematics in China and the United States. Mahwah, N.J.: Lawrence Erlbaum Associates.

Marton, F., \& Tsui, A. B. M. (2004). Classroom discourse and the space of learning. Mahwah, N.J.: Lawrence Erlbaum Associates.

Moore, T. G. (2000). China and globalization. In S. S. Kim (Ed.), East Asia and globalization (pp. 105-132). Maryland: Rowman and Littlefield Publishers.

Nonna, N., Tajima, H. T., \& Minamoto, K. (2004). Japan. In K. W. Ho \& R. Y. L. Wong (Eds.), Language policies and language education: The impact in East Asian 
countries in the next decade (Second ed., pp. 139-171). Singapore: Eastern University Press.

Nozaki, Y., Openshaw, R., \& Luke, A. (2005). Introduction. In Y. Nozaki, R. Openshaw \& A. Luke (Eds.), Struggles over difference: Curriculum, texts, and pedagogy in the Asia-Pacific. Albany: SUNY Press.

Paine, L. W. (1990). The teacher as virtuoso: A Chinese model for teaching. Teachers College Record, 92(1), 49-81.

Pham, H. H. (2000). The key socio-cultural factors that work against success in tertiary English language training programs in Vietnam. Paper presented at the Teaching at the Mekong Institute: applying the AIM approach. Proceedings of the Fourth International Conference on Language and Development, Hanoi, Vietnam.

Phan, V. H., \& Faulkner, L., A. (2000). Exploring change: A case study. Paper presented at the Teaching at the Mekong Institute: applying the AIM approach. Proceedings of the Fourth International Conference on Language and Development, Hanoi, Vietnam.

Sonntag, S. K. (2007). Change and permanence in language politics in Nepal. In A. B. M. Tsui \& J. W. Tollefson (Eds.), Language policy, culture, and identity in Asian contexts (pp. 205-217). Manwah, N.J.: Lawrence Erlbaum Associates.

Stevenson, H. W., \& Stigler, J. W. (1992). The learning gap: Why our schools are failing and what we can learn from Japanese and Chinese education. New York: Touchstone.

Stigler, J. W., \& Hierbert, J. (1999). The teaching gap: Best ideas from the world's teachers for improving education in the classroom. New York: The Free Press. 
Tsui, A. B. M. (2004). Language policies in Asian countries: Issues and tensions. The Journal of Asia TEFL, 1(2), 1-26.

Tsui, A. B. M. (in press). The complexities of identity formation: A narrative inquiry of an EFL teacher. TESOL Quarterly.

Tsui, A. B. M., \& Bunton, D. (2000). The discourse and attitudes of English teachers in Hong Kong. World Englishes, 19(3), 287-304.

Tsui, A. B. M., \& Tollefson, J. W. (2004). The centrality of medium-of-instruction policy in sociopolitical processes. In J. W. Tollefson \& A. B. M. Tsui (Eds.), Medium of instruction policies: Which agenda? whose agenda? (pp. 1-18). Mahwah, N.J.: Lawrence Erlbaum Associates.

Tsui, A. B. M., \& Tollefson, J. W. (2007). Language policy and the construction of national cultural identity. In A. B. M. Tsui \& J. W. Tollefson (Eds.), Language policy, culture, and identity in Asian contexts (pp. 1-21). Mahwah, N.J.: Lawrence Erlbaum Associates.

Yim, S. (2003). Globalization and national identity: English-language textbooks in Korea. Unpublished doctoral dissertation, The Steinhardt School of Education, New York University.

Yim, S. (2007). Globalization and language policy in South Korea. In A. B. M. Tsui \& J. W. Tollefson (Eds.), Language policy, culture, and identity in Asian contexts (pp. 3753). Mahwah, N.J.: Lawrence Erlbaum Associates. 